\title{
Men's Participation to Support Early Detection of Cervical Cancer in Indonesia: A Literature Review
}

\author{
Tiyas Kusumaningrum \\ Faculty of Nursing, Universitas Airlangga \\ Surabaya, Indonesia \\ tiyas-k@fkp.unair.ac.id
}

\begin{abstract}
The number of cervical cancer patients in Indonesia is increasing every year. It triggers the government organize cervical cancer early detection program. Many women have taken advantage of the program, but the number of the inspection Visual Inspection Acetate (VIA) and Pap-smear still very low nationwide. A lot of research trying to uncovered the reason for the early detection of low coverage including factors that motivate women to take VIA / Pap-smear. Among the factors that often studied was the husband's support to the implementation of such screening. Most of the existing research using data obtained from the wife or women, so male participation in supporting the implementation of early detection of cervical cancer remain unclear. Articles search via Google Scholar. The search was limited to Indonesia language. The keywords used were men; husband; cervical cancer; VIA; and Pap-smear. Result: There were 54 articles were found. After filtering out duplicate articles and focus the search results on early detection of cervical cancer, conducted a review of nine articles accordingly. Eight articles is quantitative and one qualitative research articles. Based on the review, it was found that most studies show that women get support from the husband, but the number of examination remains low. Almost all research takes data from samples of women to illustrate the husband's support in the implementation of early detection of cervical cancer. Discussion: This review shows that approach of research that has been done to determine the role and participation of men in the implementation of early detection of cervical cancer are still using women's perspectives approach. Another approach is needed to give a clear picture of participation carried out by men and aspects that could be improved from this participation.
\end{abstract}

Keywords-VLA; Pap-smear; participation; cervical cancer

\section{INTRODUCTION}

The increasing number of cancer deaths in women requires a comprehensive response. Female deaths from cancer in Indonesia are largely caused by breast cancer and cervical cancer. Cervical cancer is a preventable disease when it was found in precancerous stage [1]. The government has taken steps over the handling of both types of cancer. In addition to the treatment of cancer, early detection conducted throughout Indonesia, involving various agencies and organizations both governmental and non-profit organizations. Screening activities undertaken are Visual Inspection Acetate (VIA) and Papsmear. The government tried to increase the coverage VIA and Pap-smear for cervical cancer through awareness, early detection, and some women's empowerment programs. Target set by the government for the detection of cervical cancer and breast cancer is 50 percent of the population [2]. VIA had high possibility to perform and trusted as a choice of cervical screening [3]. However, the number of VIA examination and Pap-smear are still far from expectations [4]. There were many studies conducted to determine the factors associated with the coverage number of VIA and Pap-smear in Indonesia. Most of these studies collected data from women, especially women of childbearing age.

Husband support to the implementation of early detection of cervical cancer is one factor that is often studied. Data for husband's support was largely obtained from women, thus results of most existing research using the approach from women's perspectives. To give a clear picture of male participation in early detection of cervical cancer, literature review was required.

\section{METHOD}

Articles searched trough Google Scholar. The search was limited to Indonesian language. The keywords used were men; husband; cervical cancer; VIA; and Pap-smear. This study limited to articles from 2014 till recently. Reduction of duplicate articles was applied.

\section{RESULT}

There were 54 articles from various type was found. There were numbers of articles have duplication records. These duplications were removed from the list of articles. Some articles are not associated with cervical cancer detection, VIA, or Pap-smear than removed from the list of literatures. Several articles that full papers were inaccessible also removed from the list of reviews. Nine articles were reviewed in this study. Eight articles were quantitative and one was qualitative research article.

The majority of researches were quantitative research with cross sectional approach. Besides men's participation which mentioned as husband's support, some factors such as age, level of education, knowledge, and level of economic also being investigated. All data used in quantitative researches taken from women using questionnaires. One qualitative research collected data from different types of samples: women, husband, and midwives. Data collected for qualitative research was from in-depth interview. 


\section{DISCUSSION}

Cervical cancer is the most common type of gynecological cancer in women [5]. This type of cancer is also the most common cancer suffered by women in developing countries [6]. Early detection is important to prevent morbidity and mortality on women from cervical cancer. Husband's support became an important factor that can provide reinforcement to motivate women carry out early detection of cervical cancer [7]. Low of men's participation can lead to low number of cervical cancer screening nationally.

Research in Jember about correlation on husband's support and wife behavior on cervical cancer prevention reveal that most women had less support from the husband. Over $60 \%$ of women had bad behavior, among them more than $20 \%$ receive good support from their husbands [7]. Men's participation data was collected from the women and there were no clear description about men's point of view about the support they gave for cervical cancer prevention including cervical screening. However, the research gave insight about the importance of men's support on preventing cervical cancer.

A research in Bantul investigated the correlation between husband's supports with early detection of cervical cancer in mothers found that $80 \%$ of the sample did not performed AVI or Pap-smear screening. Husband's support was divided into four categories: information, appraisal, instrumental, and emotional. Women receive less support from all four categories and only about $35 \%$ receive good support from the husband [8]. This research used approximately 30 respondents only and the research conducted at region that has the lowest screening number, thus lead some bias on the result. This study also took data from women only without clarified the data with husband, while the questions being ask in the questionnaire was mostly about men's action toward cervical cancer screening.

A study about knowledge, motivation, and husband's support on VIA examination showed knowledge and motivation of women, also husband's support has influence on AVI screening [9]. However, there were no explanations about the form of husband's supports. This research also failed to explain about how men participated in early detection of cervical cancer.

A correlation study about factors related to women willingness to perform cervical screening found only half of the samples received husband's support and less than $20 \%$ visit the health care center for the examination. Other than that, majority of respondents has lack of knowledge and negative attitude toward cervical cancer screening. This study only describe men's support as "supported" and "not supported" [10]. The chi-square result showed there was a correlation between husband's support and women willingness to perform screening. Similar study at Temanggung also revealed that husband's support correlated with AVI screening [11]. However, from this two studies we cannot conclude what kind of support being performed by the husband.

A slight different study about factors related to AVI/Papsmear examination targeted women in empowerment group. There were 191 samples, all of which active on women empowerment activities. Despite the high percentage of husband's support (78.5\%), only $14.7 \%$ among the percentage has done AVI/Pap-smear. Husband's support only categorized as "supported" and "not supported" only, thus make it hard to know what action of support given. This result aligned with study at Lampung about similar factors. There were 11 factors being looked up: age, education, occupation, economic status, husband's support, attitude, knowledge, information, role of health volunteer, values, and fear. All factors found to be correlated with detection of cervical cancer except knowledge. Husband's support received by $51.5 \%$ of women but more than $80 \%$ of samples not performing screening [12]. None of specific description about husband's support in the study except it was correlated with cervical cancer detection.

One study examined couple motivation of fertile age to perform AVI using 33 women that already had AVI as samples. From this study we knew that intrinsic motivation was higher (approximately 63.6\%) compared to extrinsic motivation (approximately 54.5\%) [4]. Despite its clear title of using couple motivation as main variable of the study, the samples being used only woman. For the extrinsic motivation in doing AVI, there was no information whether men or partner's participation also included in the questionnaires.

One qualitative study about couple commitment on Papsmear examination used three different types of samples. First were women, second samples were their husbands, and last were the midwives. Data collected using in-depth interview for all samples. This study found that majority of women had good support from their husbands; however most of it refused to take the examination due to individual fear. From in-depth with midwifes found that there are socialization program of Papsmear, also a free examination program supported by the government and other agencies [13]. Despite its diversification of samples, there were not enough explanation or factual prove of husband's point of view about their support on women doing Pap-smear.

\section{CONCLUSION}

There were many quantitative research approach being published about men support and participation on early detection of cervical cancer in Indonesia, however there were less of the research using men as the source of data. Those lead to less understanding and less balance information about men's actual participation on cervical cancer screening.

Qualitative research being done in this kind of topic might bring more opportunity to explore men actions about cervical cancer screening. Unfortunately, this kind of research approach was not popular among researcher in Indonesia.

All result of men's participations among reviewed study in this article suggested that husband's support still have room for improvement. More study using men as the source of data, were promoted to gain better insight about men's participations on supporting early detection of cervical cancer in Indonesia.

\section{REFERENCES}

[1] A. O. Raifu, M. El-Zein, G. Sangwa-Lugoma, A. Ramanakumar, S. D. Walter, E. L. Franco, and F. the C. S. S. Group, "Determinants of Cervical Cancer Screening Accuracy for Visual Inspection with Acetic 
Acid (VIA) and Lugol?s Iodine (VILI) Performed by Nurse and Physician," PLoS One, vol. 12, no. 1, p. e0170631, Jan. 2017.

[2] KEMENKES RI, PANDUAN PROGRAM NASIONAL GERAKAN PENCEGAHAN DAN DETEKSI DINI KANKER KANKER LEHER RAHIM DAN KANKER PAYUDARA. Jakarta: Kementrian Kesehatan Repubilk Indonesia, 2015.

[3] A. Dumont, N. Bessières, A. Benbassa, G. Razafindrafara, F. Rabearison, and H.-J. Philippe, "Dépistage du cancer du col utérin en milieu rural à Madagascar : faisabilité, couverture et incidence,” J. Gynecol. Obstet. Hum. Reprod., vol. 46, no. 4, pp. 327-332, 2017.

[4] C. Ningrum, "MOTIVASI PASANGAN USIA SUBUR DALAM MELAKUKANPEMERIKSAAN IVA TEST (INSPEKSI VISUAL ASAM ASETAT) DI WILAYAH KERJA PUSKESMAS SEWON 1 BANTUL," Stikes Jenderal Achmad Yani Yogyakarta, 2016.

[5] G. Cunningham, Williams Obstetrics, 22nd ed. New York: McGRAWHILL, 2005

[6] F. Ali, R. Kuelker, and B. Wassie, "Understanding cervical cancer in the context of developing countries," Ann. Trop. Med. Public Heal., vol. 5, no. 1, p. 3, 2012.

[7] S. Musyriqoh, "HUBUNGAN DUKUNGAN SUAMI DENGAN PERILAKU PENCEGAHAN TERHADAP KANKER SERVIKS PADA WANITA DEWASA AWAL DI DESA BALUNG LOR KECAMATAN BALUNG KABUPATEN JEMBER," Universitas Jember, 2016

[8] F. D. Anggraeni, "GAMBARAN DUKUNGAN SUAMI TERHADAP DETEKSI DINI KANKER SERVIKS PADA PASANGAN USIA
SUBUR (PUS) DI DUSUN NGASEM DESA TIMBULHARJO SEWON BANTUL TAHUN 2016," Media Ilmu Kesehat., vol. 5, no. 3, pp. 184-192, 2016.

[9] I. Kurniawati, "PENGARUH PENGETAHUAN, MOTIVASI DAN DUKUNGAN SUAMI TERHADAP PERILAKU PEMERIKSAAN IVA PADA KELOMPOK WANITA USIA SUBUR DI PUSKESMAS KEDUNGREJO.” Universitas Sebelas Maret, 2015.

[10] I. S. Lestari, Y. Kusumastuti, and K. E. Werdani, "Faktor-faktor yang mempengaruhi kesediaan wus dalam melakukan deteksi dini kanker serviks di puskesmas manahan surakarta," Universitas Muhammadiyah Surakarta, 2016

[11] F. T. Parapat, "Faktor Faktor Yang Berhubungan Dengan Perilaku Deteksi Dini Kanker Leher Rahim Metode Inspeksi Visual Asam Asetat Di Puskesmas Candiroto Kabupaten Temanggung," Universitas Diponegoro, 2016

[12] C. A. Febriani, "Related Factors with Early Detection of Cervical Cancer at Gisting Subdistrict, Tanggamus District, Lampung," J. Kesehat., vol. 7, no. 2, p. 10, 2016.

[13] E. T. Handayani and N. Ningtiyasari, "KOMITMEN PUS TENTANG PELAKSANAAN PAP SMEAR UNTUK MENCEGAH KANKER SERVIKS di PUSKESMAS NGUNUT KABUPATEN TULUNGAGUNG TAHUN 2014,” J. BONOROWO, vol. 2, no. 1, pp. 45-53, 2014. 